[DOI: 10.24214/jecet.A.9.2.27280.]

Jaurnal of Environmental Science, Computer Science and Engineering \& Technology

An International Peer Review E-3 Journal of Sciences and Technology

Available online at www.jecet.org

Section A: Environmental Science

Research Article

\title{
Carcass quality evaluation of broilers fed with black soldier fly (Hermetia Illucens) larvae
}

\author{
Christine Jay L. Balolong1, Banisa S. Jumawan², and Erma C. Taer ${ }^{3}$ \\ 1,2, Negros Oriental State University-Pamplona Campus, Pamplona Negros Oriental \\ ${ }^{3}$ Surigao State College of Technology-Mainit Campus, Mainit, Surigao del Norte
}

Received: 07 March 2020; Revised: 22 March 2020; Accepted: 30 March 2020

\begin{abstract}
The unceasingly growing human population and the concurrent decline of agricultural production begets a serious demand for quality protein sources. A 35 days trial was initiated to evaluate the carcass quality and proximate composition of broiler chicken meat supplemented with increasing levels of Black Soldier Fly Larvae (BSFL) as feed protein sources. There were five tested diets; T0 (100\% Commercial Feeds) as control, T1 (75\% CF + 25\% BSFL), T2 (50\%, CF + 50\% BSFL), T3 (25\% $\mathrm{CF}+75 \% \mathrm{BSFL})$ and $\mathrm{T} 4$ (100\% BSFL) using one hundred twenty (120) unsexed day-old Cobb-500 broilers grouped into 8 birds per replicate in three replications under five treatments. The data were analyzed using a one-way analysis of variance (ANOVA) in a completely randomized design (CRD) to determine which treatments significantly differ. The performance results showed that there was no significant difference between treatments in the carcass recovery of meat as well as its organoleptic tests. The crude protein, crude fat and crude fiber of the tested chicken meat was highest in T0, T4 and T3 having $13.03 \%, 10.40 \%$, and $0.77 \%$ respectively. The levels of moisture were high under T2 with $72.12 \%$ and ash was $1.22 \%$ high on both T0 and T2. The carcasses of broiler chicken supplemented with BSFL can be marketed and acceptable to the consumers. Moreover, the BSFL can be a valuable feed protein supplement to broilers without detrimental effects on the quality of meat.
\end{abstract}

Keywords: Black Soldier Fly Larvae, Insects, Meat Quality, Organoleptic Test, Proximate Composition 


\section{INTRODUCTION}

The world faces a remarkable food security challenge in the twenty-first century. Providing all people with healthy and environmentally sustainable food at all times is thus one of the greatest challenges facing society today ${ }^{[1]}$. Due to the population increase and increase in disposable income, the global demand for animal protein is increasing with an expected continual rise in protein cost both for animal and human use. Bruinsma, ${ }^{[2]}$ stated that global agricultural food production output should increase production to approximately 200 million tons of livestock meat to feed the growing population.

Broiler production is one of the major economical and easiest means of bridging the supply-demand gap of animal protein due to its rapid growth rate and superior feed conversion ratio ${ }^{[3]}$. However, in the poultry and livestock industry, feed is the main issue as it covers a large portion of the cost of production. Modern poultry production aims to reduce feed cost for the optimal economic returns because feed alone contributes about $60-70 \%$ of the total cost of production ${ }^{[4]}$. Increased production of poultry requires larger amounts of protein to meet the essential amino acid demands for plumage, growth and egg production ${ }^{[5]}$.

Using insects to feed animals seems to be much more acceptable for consumers ${ }^{[6]}$. Insects consist of a larger amount of protein, that ranges to as high as $64 \%{ }^{[7]}$ to as low as $39.16 \%{ }^{[8]}$ with a higher amount of essential amino acids. Such that, BSFL is a potential feed ingredient for use in animal consumptions as it is high in protein and energy. The black soldier fly larva meal was utilized live, chopped, dried and ground forms. Attempts have been made to produce a defatted BSFL meal by chopping the larvae to allow the discharge of intracellular fat and then transferring the material to a tincture press ${ }^{[9]}$. As part of a balanced diet, the BSFL meal was found to support the good growth of the chicks. Chicks given a diet consisting dried BSFL (as a replacement for soya meal) improved weight to as high of $96 \%$ (non-significant) from that of chicks given the soya meal containing (control diet), but they only eat up to significant (93\%) higher of consumed feed ${ }^{[10]}$, recommended larvae meal diet as highly feed conversion efficiency capacity. Moreover, they have been utilized to produce valuable feed resources for cattle, pigs, poultry, and fish ${ }^{[10]}$. According to Aniebo et al. ${ }^{[1]}$ the proximate nutritional value of BSFL is not constant depending on the processing method. One of the advantages of BSF is that, unlike many waste-consuming pests, BSF carries no bacteria or diseases and larvae can inactivate Escherichia coli and Salmonella enterica ${ }^{[12]}$. Based on the abovementioned findings, this research was initiated to evaluate the effect of increasing levels of black soldier fly $(H$. illucens) larvae dietary supplementation ( $25 \%$ to $100 \%)$ on the carcass quality and meat sensory acceptability of broiler chicken.

\section{MATERIALS AND METHODS}

Location and duration: A thirty-five (35) days study was conducted from January 5 to February 10 , 2019, at the poultry section of Negros Oriental State University (NORSU) in Pamplona Campus, Pamplona, Negros Oriental using one-hundred twenty (120) heads commercial broiler chicks. The birds were raised according to the standard management practices for broilers. Restricted feeding was done twice daily (6 AM-6 PM) with black soldier fly larvae and commercial feeds according to their corresponding treatment applications while Ad libitum clean water was provided in plastic waterers.

Experimental design: The study was a single-factor experiment laid out in a Completely Randomized Design (CRD) with five treatments. Each treatment was replicated three times with eight birds per replication. Broiler chickens were the representative samples of the different treatments formulated with various experimental diets. The experimental diets formulated in each treatment with the supplement and level of application are the following; $\mathrm{T}_{0}\left(100 \%\right.$ Commercial Feeds) as control, $\mathrm{T}_{1}$ 
(75\% Commercial Feeds $+25 \%$ BSFL), $\mathrm{T}_{2}\left(50 \%\right.$, Commercial Feeds $+50 \%$ BSFL), $\mathrm{T}_{3}(25 \%$ Commercial Feeds $+75 \%$ BSFL) and $\mathrm{T}_{4}(100 \%$ BSFL $)$.

Larvae collection and feeding: One (1) kilo of cultured black soldier fly larvae was purchased from a reliable farmer mixed with kitchen food wastes which primarily composed of rotten fruits, vegetables, and spoiled meat were placed in an open container (plastic) as black soldier fly egg traps and substrate. The substrates were rewatered to remain moist and the ambient temperature was kept not to exceed $30^{\circ} \mathrm{C}$. To collect larvae, the surface substrate layers were removed until the larvae were exposed. Immediately after the collection, the BSF larvae were weighed and fed fresh to broilers. On the thirty-fifth (35) day of the rearing period, birds were fasted for twelve (12) hours to achieve clean entrails upon slaughtering. Only water was available in each pen until the birds were slaughtered. Five (5) out of eight (8) birds were selected randomly as experimental samples subjected to slaughtering.

Slaughtering and butchery: The slaughtering process was started by cutting the jugular vein and carotid artery which are located in the lower part of the left earlobe using a sharp knife and bled for two minutes until there was no blood oozing from the artery in an improvised bleeding rack. The birds were scalded and de-feathered manually before evisceration by making an incision near the vent to cut open the abdominal cavity. The warm carcasses, viscera, heart, liver, gizzard, feet and the head were separately weighed using the digital weighing scale. The whole dressed chicken carcasses were cut according to the standard retail cuts (back, breast, wings, thigh, and drumstick) reweighed and packed into a plastic bag and placed inside the plastic cooler with ice and salt.

Proximate composition: One representative sample for each treatment subjected to laboratory analysis. The samples were stored in a freezer to avoid deterioration that will lead to the spoiling of the meat samples. Meat samples were taken from the different parts of the dressed chickens, including the skin. Immediately, the collected samples were cut and chopped into small pieces as the main specimen transported to the Department of Agriculture Regional Integrated Laboratories Division RFO-VI at Parola, Iloilo City for the analysis of crude protein, crude fat and fiber in triplicate generally following the procedure by AOAC $2002^{[13]}$. The meat moisture was evaluated through Oven Drying Method and Combustion Method was used for the analysis of ash content. The crude protein of meat was quantified by Kjeldahl Method, crude fat and crude fiber were determined through the use of the Soxhlet Indirect Method and Weende Method correspondingly. Each analysis was carried out in triplicate.

Carcass characteristics: Carcass recovery or the dressing percentage was determined by weighing the final live weight of a chicken and the weight of its dressed chicken. Carcass component yield after evisceration, the dressed chickens were chopped into retail cuts, the back, chest, wing, thing, drumstick and the giblets (heart, liver, and spleen) were removed.

Sensory evaluation: The organoleptic test of broiler chicken fed with different levels of BSFL where sensory tested viz. color, odor, tenderness, marbling, and general acceptability. A cut from a representative drumstick sample (uncooked) in every treatment was prepared, placed in a paper plate and coded according to their corresponding treatment. Before testing, the 30-man consumer and untrained panel have oriented and given score sheets to evaluate the sensory quality of broiler chicken. The sensory parameters tested were rated based on the following criteria to wit:

$>$ Color: very light pink, light pink, pinkish, light red, red.

> Odor: no off-odor, slightly perceptible off-odor, moderately perceptible off-odor, very perceptible off-odor, extremely perceptible off-odor.

$>$ Tenderness: very soft, slightly soft, just right, slightly hard, very hard 
> Marbling: no marbling, slightly perceptible marbling, moderately perceptible marbling, very perceptible marbling, extremely perceptible marbling.

$>$ General Acceptability: like extremely, like very much, like moderately, like slightly, neither like nor dislike, dislike slightly, dislike moderately, dislike very much, dislike extremely.

Statistical analysis: Significant levels were set at $P=0.05$ for all analyses. The data collected within 35 days rearing period and experimentation were statistically analyzed by one-way analysis of variance (ANOVA) in CRD using a univariate procedure in SPSS ver. 20. If a significant treatment effect was observed, the Tukey's HSD post-hoc test was applied to determine differences between treatment groups.

\section{RESULTS}

The average carcass recovery and dress weight of broiler supplemented with different levels of Black Soldier Fly Larvae are presented in Table 1. Based on the results, $73.76 \%$ was the carcass recovery of broilers fed with $100 \% \mathrm{CF}\left(\mathrm{T}_{0}\right)$ followed by $72.49 \%$ in $\mathrm{T}_{3}$ (75\% BSFL) and $71.49 \%$ in $\mathrm{T}_{1}(25 \%$ BSFL) fed chickens. However, it was found that $\mathrm{T}_{4}\left(100 \%\right.$ BSFL) and $\mathrm{T}_{2}(50 \% \mathrm{BSFL})$ fed broilers gained lower carcass recovery values with $70.55 \%$ and $69.69 \%$ respectively. Meanwhile, the meat of chicken supplemented with pure $\mathrm{CF}\left(\mathrm{T}_{0}\right)$ have higher dress weight $(822.80 \mathrm{gm})$ followed by the treatment given with 50\% BSFL (792.47 gm). Moreover, BSF larvae supplementation did not affect directly to the weight of the dressed chicken on the three (3) remaining treatments $\mathrm{T}_{3}, \mathrm{~T}_{4}$, and $\mathrm{T}_{1}$ with a meat weight of $788.47,780.80$ and 765.20 grams.

Table 1: Dressing percentage and dressing weight of broiler chicken supplemented with black soldier fly larvae

\begin{tabular}{lcc}
\hline \multicolumn{1}{c}{ Treatment } & Dressing Percentage & Dress Weight \\
\hline $\mathrm{T}_{0}(100 \%$ Commercial $)$ & $73.76^{\mathrm{ns}}$ & $822.80^{\mathrm{ns}}$ \\
$\mathrm{T}_{1}(75 \%$ Commercial $+25 \%$ BSFL $)$ & $71.49^{\mathrm{ns}}$ & $765.20^{\mathrm{ns}}$ \\
$\mathrm{T}_{2}(50 \%$ Commercial $+50 \%$ BSFL $)$ & $69.69^{\mathrm{ns}}$ & $794.47^{\mathrm{ns}}$ \\
$\mathrm{T}_{3} 25 \%$ Commercial $+75 \%$ BSFL & $72.49^{\mathrm{ns}}$ & $788.47^{\mathrm{ns}}$ \\
$\mathrm{T}_{4} 100 \%$ BSFL & $70.55^{\mathrm{ns}}$ & $780.8^{\mathrm{ns}}$ \\
\hline
\end{tabular}

${ }^{n s}$ Not significant

The proximate analysis of broiler chicken is presented in Table 2 . The analysis revealed that $\mathrm{T}_{0}$ $(100 \% \mathrm{CF})$ attained the highest amount of $\mathrm{CP}$ which is $13.03 \%$. Following to the control treatment is $\mathrm{T}_{2}\left(50 \%\right.$ BSFL), $\mathrm{T}_{4}\left(100 \%\right.$ BSFL) and $\mathrm{T}_{3}(75 \%$ BSFL) with $12.85 \%, 12.75 \%, 12.63 \% \mathrm{CP}$ respectively. Nevertheless, $\mathrm{T}_{1}(100 \%$ BSFL) obtained the least CP (12.10\%), probably because it was fed with only $25 \%$ BSF larvae. In crude fat, the $\mathrm{T}_{4}(100 \% \mathrm{BSFL})$ attained the highest value of $10.40 \%$ crude fat compared to $\mathrm{T}_{0}(100 \% \mathrm{CF})$ which is $6.28 \%$ while $\mathrm{T}_{3}(75 \% \mathrm{BSFL}), \mathrm{T}_{1}(25 \% \mathrm{BSFL})$ and $\mathrm{T}_{2}$ (50\% BSFL) recorded $8.93 \%, 6.83 \%$ and $5.97 \%$ crude fat respectively.

The crude fiber of boiler chicken meat treated with different levels of BSFL had the highest value of $0.77 \%$ found on $\mathrm{T}_{3}(75 \% \mathrm{BSFL})$. In contrast, $\mathrm{T}_{0}(100 \% \mathrm{CF})$ got the lowest crude fiber value which is $0.13 \%$ only. Moreover, the least value is also observed in $\mathrm{T}_{1}, \mathrm{~T}_{4}$, and $\mathrm{T}_{2}$ with $0.50 \%, 0.48 \%$, and $0.40 \%$ content of crude fiber. The moisture content of chicken carcasses revealed that $\mathrm{T}_{2}(50 \%$ BSFL) obtained the highest content of moisture which is $75.12 \%$. Meanwhile, upon observation, four treatments contained closely related value of moisture. $\mathrm{T}_{4}\left(100 \% \mathrm{BSFL}\right.$ ) gained $73.49 \%, \mathrm{~T}_{0}$ (Control) had $73.4 \%, \mathrm{~T}_{1}(25 \% \mathrm{BSFL})$ achieved $73.12 \%$ and $71.3 \%$ moisture was found in the carcass of $\mathrm{T}_{3}$ 
(75\% BSFL). The ash content on the meat samples showed $\mathrm{T}_{0}$ (control) and $\mathrm{T}_{2}(50 \% \mathrm{BSFL}$ ) were observed to have an ash content of the same value of $1.22 \%$. On one hand, $1.15 \%$ was found in $\mathrm{T}_{4}$ (100\% BSFL) and $1.06 \%$ in $\mathrm{T}_{1}(25 \% \mathrm{BSFL})$ and $0.99 \%$ in $\mathrm{T}_{3}(75 \%$ BSFL) respectively.

Table 2: Proximate composition of meat sample

\begin{tabular}{llllll}
\hline \multicolumn{1}{c}{ Treatment } & Crude Protein & Crude Fiber & Crude Fat & Moisture & Ash \\
& & & & & \\
\hline T0 (100\% Commercial) & $13.03^{\mathrm{ns}}$ & $0.13^{\mathrm{ns}}$ & $6.28^{\mathrm{ns}}$ & $73.4^{\mathrm{ns}}$ & $1.22^{\mathrm{ns}}$ \\
T1 $(75 \%$ Commercial + 25\% BSFL $)$ & $12.1^{\mathrm{ns}}$ & $0.5^{\mathrm{ns}}$ & $6.83^{\mathrm{ns}}$ & $73.12^{\mathrm{ns}}$ & $1.06^{\mathrm{ns}}$ \\
T2 (50\% Commercial + 50\% BSFL) & $12.85^{\mathrm{ns}}$ & $0.4^{\mathrm{ns}}$ & $5.97^{\mathrm{ns}}$ & $75.12^{\mathrm{ns}}$ & $1.22^{\mathrm{ns}}$ \\
T3 25\% Commercial + 75\% BSFL & $12.63^{\mathrm{ns}}$ & $0.77^{\mathrm{ns}}$ & $8.93^{\mathrm{ns}}$ & $71.3^{\mathrm{ns}}$ & $0.99^{\mathrm{ns}}$ \\
T4 100\% BSFL & $12.75^{\mathrm{ns}}$ & $0.48^{\mathrm{ns}}$ & $10.4^{\mathrm{ns}}$ & $73.49^{\mathrm{ns}}$ & $1.15^{\mathrm{ns}}$ \\
\hline \hline
\end{tabular}

ns Not significant

In organoleptic tests, the ANOVA for all attributes viz. color, odor, tenderness, marbling, and general acceptability revealed no significant differences among the meat in different treatments as shown in Table 3. However, the birds supplemented with 50\% BSFL $\left(\mathrm{T}_{2}\right)$ plainly shows the highest acceptability mean score of color, tenderness, and marbling at 6.5, 6.97 and 6.87 while the $100 \%$ commercial $\left(\mathrm{T}_{0}\right)$ was higher in acceptability scores in meat odor and general acceptability scores of 5.5 and 6.73 respectively. Moreover, the treatments $\mathrm{T}_{1}(25 \% \mathrm{BSFL}), \mathrm{T}_{3}(75 \% \mathrm{BSFL})$, and $\mathrm{T}_{4}(100 \%$ BSFL) have similar slightly lesser values of costumer acceptability scores

Table 3: Organoleptic scores of broiler meat samples

\begin{tabular}{lccccc}
\hline \multicolumn{1}{c}{ Treatment } & Color & odor & Tenderness & Marbling & $\begin{array}{c}\text { General } \\
\text { acceptability }\end{array}$ \\
\hline $\mathrm{T}_{0}(100 \%$ Commercial $)$ & $5.87^{\mathrm{ns}}$ & $5.50^{\mathrm{ns}}$ & $6.63^{\mathrm{ns}}$ & $6.63^{\mathrm{ns}}$ & $6.73^{\mathrm{ns}}$ \\
$\mathrm{T}_{1}(75 \%$ Commercial $+25 \%$ BSFL $)$ & $6.30^{\mathrm{ns}}$ & $4.43^{\mathrm{ns}}$ & $6.93^{\mathrm{ns}}$ & $6.80^{\mathrm{ns}}$ & $6.60^{\mathrm{ns}}$ \\
$\mathrm{T}_{2}(50 \%$ Commercial $+50 \%$ BSFL $)$ & $6.50^{\mathrm{ns}}$ & $5.03^{\mathrm{ns}}$ & $6.97^{\mathrm{ns}}$ & $6.87^{\mathrm{ns}}$ & $6.43^{\mathrm{ns}}$ \\
$\mathrm{T}_{3} 25 \%$ Commercial + 75\% BSFL & $6.03^{\mathrm{ns}}$ & $5.10^{\mathrm{ns}}$ & $6.60^{\mathrm{ns}}$ & $6.77^{\mathrm{ns}}$ & $6.27^{\mathrm{ns}}$ \\
$\mathrm{T}_{4} 100 \%$ BSFL & $6.10^{\mathrm{ns}}$ & $5.30^{\mathrm{ns}}$ & $6.70^{\mathrm{ns}}$ & $6.37^{\mathrm{ns}}$ & $6.37^{\mathrm{ns}}$ \\
\hline
\end{tabular}

${ }^{\mathrm{ns}}$ Not significant

\section{DISCUSSIONS}

Broilers fed with pure commercial feeds got the highest carcass recovery compared to those birds supplemented and given with pure BSF larvae. Further, the inclusion of BSF larvae on chicken broiler diets did not $(p>0.05)$ influence dressing percentage when subjected to ANOVA. Similar results were found on a study conducted by Cockcroft ${ }^{[14]}$ where broilers were supplemented with BSF larvae meal in different preparations (full fat, dry rendered, extruded). She disclosed that the dressing percentage parameter of the chickens has no significant difference between treatments.

The mean weight of dressed chicken supplemented with BSFL was likewise not significant to a commercial diet ( $\mathrm{T}_{1}$ control). This conforms to the findings of Cullere et al. ${ }^{[15]}$ on the supplementation of BSF on quails which had similar productive performance, mortality, and carcass traits in all experimental unit. Statistical analysis revealed that there was no significant difference in 
the weight of the dressed chicken in four (4) treatments supplemented with BSF larvae including treatment as control. This agrees with the findings of Uushona ${ }^{[16]}$, that inclusion of black soldier fly pre-pupae meal (BSM) in broiler chicken feed ration did not influence live slaughter weight, cold carcass weight, and dressing percentage. Neither did treatment influence the commercial portion cut yield of the breast, thigh, drumstick, and wing and back of the broiler carcasses. Oluokun ${ }^{[17]}$ stressed that the diet enhanced with the larvae meal did not influence the weight gain, feed intake, or the feed/gain ratio regarding the fish meal. Moreover, there were increases in the carcass yield, weight on entrails (kidney, gizzard, and liver), and bird's abdominal fat when fed with larvae diet compared with a fish meal or control diet. In this proceedings, internal organs were not measured but carcass yield in $\mathrm{T}_{2}(50 \%$ Commercial $+50 \%$ BSFL) showed improvements over the other treatment groups.

Jung et al. ${ }^{[18]}$, proximate composition of commercial broiler chicken thigh meat in three (3) different production stages (stage 1 at $1.14 \mathrm{~kg}$, stage II at $1.57 \mathrm{~kg}$, and stage II at $1.99 \mathrm{~kg}$ ) ranges from $16.90 \%$ 16.97\% Crude Protein, 5.80\% - 6.59\% Crude Fat, 73.89\% - 74.40\% Moisture and 0.99\% - 1.03\% Ash respectively. This evidence conforms to the findings of the current study that there are similarities in the meats' proximate composition. Tran et al. ${ }^{[19]}$, statement that insects are part of the natural diets of wild birds and free range-poultry. Thus, BSF larvae can provide $40 \%$ to $44 \%$ valuable protein-rich feedstuff with a better amino acid profile. On the other hand, the crude protein content was a bit higher than that of the CP from the current study $(12.10 \%-13.03 \%)$. This may have been affected by the feeding scheme of the birds where they were feed restrictedly thus possibly lowering their CP. The fat and protein makeup can differ depending on growing substrate characteristics ${ }^{[6,20,21]}$. Similarly, the composition of fat of the growing substrate may have resulted in a higher fat content in the $100 \%$ BSFL supplemented chicken in this experiment (10.40\%). This upholds the study made by St-Hilaire et al. [22], that BSF larvae are likewise abundant in fat which has an extreme quantitative (15\% to $49 \%$ ) and qualitative variations depending on the chemical nutrient composition of the rearing substrate.

Consumers' demand for meat products depends on many criteria such as species of animal, age, sex and eating quality factors like flavor, tenderness, juiciness, color, texture and over-all acceptability which are on large scale determined by the water holding capacity of the meat. Organoleptic properties of meat products are very important as these combined to give an overall assessment of meat quality and determinants of the decision of consumers to demand and repurchase.

Comparing the differences among the averages of the scores of different organoleptic attributes showed no significant effects on all treatments tested. The result on the meat color attribute coincides with the findings of Hwangbo et al. ${ }^{[23]}$, where broilers fed with BSFL had no significant differences in its meat color regarding the CIElab $L^{*}, a^{*}$ and $b^{*}$ values. This suggests that the use of insects on broiler diets may either produce the same meat color as conventionally used sources of proteins or even produce better color when included at different levels or when other insects are investigated. A study by Uushona, ${ }^{[16]}$ performing organoleptic tests on cooked meat found no significant differences in any of the meat proximate analysis components whilst investigating BSF pre-pupae at different inclusion levels for broiler diets. Although Uushona's study was done on cooked meat samples, while the current study used raw meat samples, there could have been a possible similarity in the results which influenced the composition of the meat. Having no significant differences between treatments in its carcass recovery and the organoleptic test may have been attributed to the kind of feed given which is fresh black soldier fly larvae. BSF is a living organism that makes it composed of $60-70 \%$ water. This may have affected the carcass characteristics for broiler performance which depends on the metabolizable energy and crude protein of a diet ${ }^{[24]}$.

The statistical analysis revealed no significant difference in the general acceptability among the treatments. This only means that the acceptability of the meat does not have a variation between treatments. The viability of black soldier fly meal as an alternative protein source in broiler chickens is not only proven based on its ability to maintain growth but also on its meat quality. The inclusion of 
BSM in broiler diets did not influence the quality of the meat produced nor compromise the meat's eating quality as no taste discrimination was observed by DSA utilizing trained panelists ${ }^{[16]}$.

\section{CONCLUSION}

Based on the above findings, it was discovered in this study that the supplementation of Black Soldier Fly Larvae in different levels $25 \%, 50 \%, 75 \%, 100 \%$ did not affect the carcass quality of broiler chicken. It can be concluded that the carcass of broilers supplemented with Black Soldier Fly can be distributed in the market and consumed without any adverse effects on the consumer preferences. Moreover, it can be suggested that BSFL can be a viable feed protein supplement to broilers without negative effect on the meat quality and organoleptic traits.

\section{RECOMMENDATION}

Since the following results are preliminary, the following recommendations are given:

1. As fresh BSF is supplemented to the chicken, it can be recommended that the next researchers may use dried Black Soldier Fly larvae. Through the process of drying the feed, the moisture content will decrease which may significantly affect the growth and carcass quality of the chicken.

2. To the Engineering Department of NORSU, it is recommended by the researchers to make a pelletizer for the efficient making of a new feed, which is a black soldier fly larvae meal, and for it to be used by the next researcher who wants to carry on the study.

3. Mass production of Black Soldier Fly larvae to be supplemented to broiler chicken on an ad libitum basis.

4. Determine the $\mathrm{pH}$ of meat as it affects several parameters in the carcass attributes like color, tenderness, and others.

\section{REFERENCES}

1. C.Hall, T.P. Dawson, J.I. Macdiarmid, R.B. Matthews \& P.Smith, The impact of population growth and climate change on food security in Africa: looking ahead to 2050. International Journal of Agricultural Sustainability, 2017, 15(2), 124-135.

2. J. Bruinsma, The resource outlook to 2050: by how much do land, water and crop yields need to increase by 2050. In Expert meeting on how to feed the world in (Vol. 2050, pp. 2426)2009.

3. P.N.Onu, M.O. Otuma, C.A. Odukwe \& A.O.Aniebo, Effects of different levels of bovine blood/rumen content mixture on productive performance, carcass characteristics and economics of production of finisher broilers. Int. J. Food Agric. Vet. Sci, 2011, 1(1), 10-16.

4. J. Hinrichs \& H. Steinfeld, Feed availability inducing structural change in the poultry sector, 2007, Poultry in the 21st Century. http://www. fao. org/Ag/againfo/home levents /bangkok.

5. S.M.Hossain \& R.Blair, Chitin utilisation by broilers and its effect on body composition and blood metabolites. British poultry science, 2007, 48(1), 33-38.

6. H.P.Makkar, G. Tran, V. Heuzé \& P. Ankers, State-of-the-art on use of insects as animal feed. Animal Feed Science and Technology, 2014, 197, 1-33. 
7. Hwangbo, J., Hong, E. C., Jang, A., Kang, H. K., Oh, J. S., Kim, B. W., \& Park, B. S. (2009). Utilization of house fly-maggots, a feed supplement in the production of broiler chickens. Journal of Environmental Biology, 2009, 30(4), 609-614.

8. Atteh, J. O., \& Ologbenla, F. D. (1993). Replacement of fish meal with maggots in broiler diets: effects on performance and nutrient retention. Nigerian Journal of Animal Production, 1993, 20(1), 44-49.

9. Kroeckel, S., Harjes, A. G., Roth, I., Katz, H., Wuertz, S., Susenbeth, A., \& Schulz, C. (2012). When a turbot catches a fly: Evaluation of a pre-pupae meal of the Black Soldier Fly (Hermetia illucens) as fish meal substitute - Growth performance and chitin degradation in juvenile turbot (Psetta maxima). Aquaculture, 2012, 364, 345-352.

10. Newton, G. L., Sheppard, D. C., Watson, D. W., Burtle, G. J., Dove, C. R., Tomberlin, J. K., $\&$ Thelen, E. E. (2005, January). The black soldier fly, Hermetia illucens, as a manure management/resource recovery tool. In Symposium on the state of the science of Animal Manure and Waste Management (pp. 5-7). Semantic Scholar,2005.

11. Aniebo, A. O., \& Owen, O. J. (2010). Effects of age and method of drying on the proximate composition of housefly larvae (Musca domestica Linnaeus) meal (HFLM). Pakistan Journal of Nutrition, 2010, 9(5), 485-487.

12. Bava, L., Jucker, C., Gislon, G., Lupi, D., Savoldelli, S., Zucali, M., \& Colombini, S. (2019). Rearing of Hermetia Illucens on Different Organic By-Products: Influence on Growth, Waste Reduction, and Environmental Impact. Animals, 2019, 9(6), 289.

13. AOAC - Association of Official Analytical Chemistry. 2005. Official methods of analysis. AOAC International, Arlington, VA, 2005.

14. Cockcroft, B. L. (2018). An evaluation of defatted black soldier fly (Hermetia illucens) larvae as a protein source for broiler chicken diets (Doctoral dissertation, Stellenbosch: Stellenbosch University) 2018.

15. Cullere, M., Tasoniero, G., Giaccone, V., Miotti-Scapin, R., Claeys, E., De Smet, S., \& Dalle Zotte, A. (2016). Black soldier fly as dietary protein source for broiler quails: apparent digestibility, excreta microbial load, feed choice, performance, carcass and meat traits. Animal, 2016,10(12), 1923-1930.

16. T. Uushona, Black soldier fly (Hermetia illucens) pre-pupae as a protein source for broiler production (Doctoral dissertation, Stellenbosch: Stellenbosch University) 2015.

17. J.A.Oluokun, Upgrading the nutritive value of full-fat soyabeans meal for broiler production with either fishmeal or black soldier fly larvae meal (Hermetia illucens). Nigerian Journal of Animal Science,2000, 3(2).

18. Jung, Y.-K., Jeon, H.-J., Jung, S., Choe, J.-H., Lee, J.-H., Heo, K.-N., Kang, B.-S., \& Jo, C.R. (2011). Comparison of quality traits of thigh meat from Korean native chickens and broilers. Food Science of Animal Resources, 2011, 31(5), 684-692.

19. G.Tran, V. Heuzé and H.P.S. Makkar,Insects in fish diets. Animal frontiers, 2015, 5 (2), $37-$ 44.

20. T.T. Nguyen, J.K. Tomberlin \& S. Vanlaerhoven, Ability of black soldier fly (Diptera: Stratiomyidae) larvae to recycle food waste. Environmental entomology, 2015, 44(2), 406410. 
21. T. Spranghers, M. Ottoboni, C. Klootwijk, A. Ovyn, S. Deboosere, B. De Meulenaer, \& S. De Smet, Nutritional composition of black soldier fly (Hermetia illucens) prepupae reared on different organic waste substrates. Journal of the Science of Food and Agriculture, 2017, 97(8), 2594-2600.

22. S. St-Hilaire, C. Sheppard, J.K. Tomberlin, S. Irving, L. Newton, M.A. McGuire \& W. Sealey, Fly prepupae as a feedstuff for rainbow trout, Oncorhynchus mykiss. Journal of the world aquaculture society, 2007, 38(1), 59-67.

23. J. Hwangbo, E.C. Hong, A. Jang, H.K. Kang, J.S. Oh, B.W. Kim \& B.S.Park, Utilization of house fly-maggots, a feed supplement in the production of broiler chickens. Journal of Environmental Biology,2009, 30(4), 609-614.

24. Y.D. Hu, D. Lan, Y. Zhu, H.Z. Pang, X.P. Mu, \& X.F. Hu, Effect of diets with different energy and lipase levels on performance, digestibility and carcass trait in broilers. AsianAustralasian journal of animal sciences,2018, 31(8), 1275

\section{Corresponding author: BANISA S. JUMAWAN}

Instructor I; Negros Oriental State University - Pamplona Campus, Poblacion Pamplona, Negros Oriental

Email: banisajumawan01@gmail.com, Mobile number: +639434305097

Date of publication on line 30.03.2020 